\title{
mELINTAS
}

30.1 .2014 [70-104]

\section{ECO-PHILOSOPHY \\ DAN IMPLIKASINYA \\ DALAM POLITIK \\ HUKUM LINGKUNGAN \\ DI INDONESIA}

\section{Eko Nurmardiansyah}

\author{
| Postgraduate Student \\ Parahyangan Catholic University \\ Bandung, Indonesia
}

\begin{abstract}
:
Environmental crisis is rooted in a fundamental mistake of philosophical understanding or worldview (weltanschaunng) on human nature, nature, and human's place in the overall ecosystem. The solution cannot be approached only technically and partialy, but instead, in a more comprehensive-holistic way by radically changing the perspective and the nature of human behaviour, which means, they are to be tuned in to the environmental ethics. Accordingly, human behaviour is to be conceived of and conducted in line with eco-philosophy. Its political praxis is to be implemented by way of politics of law (rechtspolitiek), politics of environmental law in particular. The politics of environmental law is the policy direction to be set by the government so as to achieve the goals and objectives in the protection and the management of the environment. This, in turn, can only be implemented if the constitution as well as the legislation is already 'green'.
\end{abstract}

Keywords: eco-philosopby - environmental ethics - anthropocentrism biocentrism - ecocentrism - environmental awareness - the politics of law (rechtspolitiek) 


\section{Introduksi}

Dalam rangka mempertimbangkan aspek-aspek lingkungan hidup dan keselamatannya di masa depan Alvin Toffler mengemukakan tujuan penulisan bukunya Future Shock dengan menyatakan: "to help us come to terms with the future - to help us cope more effectively with both personal and social change by deepening our understanding of how men respond to it. Toward this end, it puts forward a broad new theory of adaptation."1 Toffler membahas masalah-masalah lingkungan hidup dengan menyatakan,

"Today, with spreading alarm over air pollution, water pollution, urban crowding and other such factors, more and more health authorities are coming around to the ecological notion that the individual needs to be seen as part of a total system, and that his health is dependent upon many subtle external factors." 2

Lingkungan hidup manusia menurut Mohamad Soerjani, dkk. seringkali disebut lingkungan hidup atau lebih singkat lingkungan saja, yang sebenarnya berakar dan berarti penerapan (aplikasi) dari ekologi dan kosmologi. Lingkungan hidup merupakan penelaahan terhadap sikap dan perilaku manusia, dengan segenap tanggung jawab dan kewajiban maupun haknya untuk mencermati tatanan lingkungan dengan sebaikbaiknya. Sikap dan perilaku ini sangat diperlukan untuk memungkinkan kelangsungan peri kehidupan secara keseluruhan, termasuk kesejahteraan manusia serta makhluk hidup lainnya. ${ }^{3}$ Undang-Undang Nomor 32 Tahun 2009 tentang Perlindungan dan Pengelolaan Lingkungan Hidup, Pasal 1 angka 1 memberikan pengertian lingkungan hidup demikian: "Lingkungan hidup adalah kesatuan dengan semua benda, daya, keadaan, dan makhluk hidup, termasuk manusia dan perilakunya, yang mempengaruhi alam itu sendiri, kelangsungan perikehidupan, dan kesejahteraan manusia serta makhluk hidup lainnya." Dalam pengertian ini, terdapat frase "termasuk manusia dan perilakunya". Kalimat tersebut menunjuk pada pengertian bahwa lingkungan hidup juga meliputi nilai manusia dan alam atau lingkungan hidup serta bagaimana manusia berperilaku berdasarkan nilai yang diberikan manusia baik atas dirinya maupun atas alam.

Berbagai kasus lingkungan hidup yang terjadi saat ini, baik pada lingkup global maupun lingkup nasional, sebagian besar bersumber dari perilaku manusia. Sebagai contoh kasus pencemaran di Sumatera 
Utara dan Papua sesungguhnya disebabkan oleh perilaku kita yang tidak bertanggung jawab terhadap lingkungan hidup, seperti disampaikan Sonny Keraf bahwa menyangkut hal ini tidak ada kepedulian dan tanggung jawab moral terhadap lingkungan hidup. ${ }^{4}$ Raymundus Sudhiarsa menyatakan bahwa krisis ekologi pada dasarnya merupakan masalah moral dan religius, artinya, krisis ini pada intinya adalah masalah kualitas manusia dan kualitas iman yang dihayati oleh orang-orang yang mengaku beragama. ${ }^{5}$ Mengenai penghayatan ini Muchtar Lubis mempertanyakan berapa di antara sekian banyak umat beragama di Indonesia yang sungguh-sungguh menghayati ajaran agama masing-masing, dan membuat ajaran agama tersebut sungguh-sungguh jadi pedoman hidup, dasar tingkah laku dan budi pekerti mereka sehari-hari. ${ }^{6}$

Kesalahan cara pandang merupakan sebab paling fundamental krisis dan bencana lingkungan hidup global, maka untuk terjadinya perubahan perilaku tersebut yang paling pokok adalah diperlukan perubahan cara pandang. Perubahan cara pandang ini harus sampai pada tataran moral, bahkan teologis.

Pada tataran moral, manusia hidup dalam sebuah komunitas moral yang tidak hanya mencakup sesama manusia. Manusia hidup dalam sebuah komunitas moral bersama seluruh kehidupan dan seluruh ekosistem. Karena itu, yang disebut sebagai komunitas moral tidak hanya menyangkut komunitas manusia, melainkan juga komunitas ekologis. Manusia tidak hanya mempunyai kewajiban dan tanggung jawab moral terhadap sesama manusia, melainkan juga terhadap kehidupan seluruhnya dan terhadap ekosistem, alam semesta, khususnya planet bumi. Atas dasar inilah, cara pandang kita terhadap alam yang selama ini bersifat antroposentris yang mengutamakan kepentingan manusia harus diubah dan diperluas. Kita perlu memiliki cara pandang baru yang lebih biosentris dan bahkan ekosentris yang memandang kehidupan dan ekosistem sebagai bernilai pada dirinya sendiri. Menjaga dan melindungi kehidupan pada umumnya serta ekosistem seluruhnya adalah sebuah tanggung jawab moral manusia sebagai pelaku moral, sama bobotnya dengan kewajiban dan tanggung jawab menghormati kehidupan sesama manusia lainnya.

Dengan cara pandang dan kesadaran baru ini diharapkan muncul perilaku baru. Cara pandang dan kesadaran baru diharapkan terjelma menjadi perilaku yang baru, perilaku yang ramah terhadap lingkungan. 
Perilaku yang dalam segala aspek menunjukkan bahwa kita memang menghormati dan memandang serius alam dan lingkungan hidup. Perilaku itu tercermin dalam kehidupan sehari-hari, dalam berbagai kebijakan yang kita buat sebagai pejabat publik dan politisi, dalam kebijakan dan pola pengembangan industri dan bisnis, dalam implementasi dan penerapan hukum yang terkait dengan lingkungan hidup. Gaya hidup baru itu harus tercermin dalam paradigma dan kebijakan pembangunan yang dipilih pemerintah. Perilaku dan gaya hidup baru ini harus terwujud dalam operasi dan sepak terjang berbagai perusahaan dan industri modern. Perilaku dan gaya hidup ini harus pula terlihat dalam bagaimana para penegak hukum menangani berbagai kasus kerusakan dan pencemaran lingkungan hidup atau pelanggaran terhadap kebijakan dan ketentuan peraturan perundangundangan terkait lingkungan hidup.

\section{Lingkungan Hidup dan Kebijakan Lingkungan Hidup}

Persoalan lingkungan merupakan persoalan kebijakan, oleh karena itu persoalan lingkungan termasuk persoalan politik. Rachmad K. Dwi Susilo menyatakan bahwa membicarakan politik juga berarti membicarakan kekuasaan (power) dan kewenangan (authority). Kemudian, membicarakan kedua-duanya akan sangat terkait erat dengan apa yang disebut sebagai kebijakan (policy). ${ }^{7}$ Oleh karena itu persoalan kebijakan di bidang lingkungan hidup merupakan kebijakan lingkungan hidup atau environmental policy. Kerusakan lingkungan hidup di Indonesia lebih disebabkan oleh kesalahan kebijakan negara daripada ulah tangan rakyat biasa, menurut Chalid Muhammad. ${ }^{8}$ Arah kebijakan hukum di bidang lingkungan hidup itu disebut dengan politik hukum lingkungan. Politik hukum lingkungan merupakan arah kebijakan hukum yang ditetapkan oleh negara atau pemerintah untuk mencapai tujuan dan sasaran dari perlindungan dan pengelolaan lingkungan hidup. Namun, dalam kenyataannya hukum lingkungan seolah tidak mampu menjalankan fungsinya dengan baik dengan munculnya berbagai masalah lingkungan hidup, salah satu penyebab masalah-masalah lingkungan hidup menurut Muhammad Akib, belum dipahami, dilaksanakan, dan ditegakkannya prinsip dan norma hukum lingkungan secara komprehensif sesuai dengan politik hukumnya. ${ }^{9}$

Penyelenggaraan pembangunan nasional haruslah bersifat 
prolingkungan atau melindungi lingkungan hidup sesuai dengan prinsip pembangunan berkelanjutan (sustainable development) yang menjamin kelangsungan hidup dan terpeliharanya daya dukung lingkungan untuk kehidupan generasi-generasi selanjutnya. ${ }^{10}$ Adanya unsur-unsur kebijakan yang prolingkungan sebagaimana Jimly Asshidiqie sampaikan bahwa UUD 1945 sebagai salah satu green constitution di dunia, meskipun nuansa hijau masih sangat tipis (light green constitution). ${ }^{11}$ Jimly Asshidiqie mengemukakan lebih lanjut hal tersebut dengan menyatakan, ${ }^{12}$

"Meskipun lingkungan hidup sudah dituangkan dalam Undang-Undang (UU Nomor 32 Tahun 2009 tentang Perlindungan dan Pengelolaan Lingkungan Hidup), tetapi begitu bergaul dengan UU Perdagangan, Perindustrian, (bahkan) dengan UU Koperasi saja, pasti UU LH akan kalah dalam praktiknya."

Unsur-unsur kebijakan yang prolingkungan walaupun telah diamanatkan dalam UUD 1945 dan dituangkan dalam peraturan perundang-undangan terkait perlindungan dan pengelolaan lingkungan hidup, namun Pemerintah sering melakukan ketidakadilan lingkungan hidup (environmental injustice), misalnya, dalam penyelesaian konflik industri pertambangan. Tuntutan keadilan yang diajukan masyarakat terhadap industri pertambangan besar, selama ini selalu menemukan jalan buntu. Permasalahan ini menjadi semakin rumit ketika pemerintah justru menjawab tuntutan tersebut dengan pernyataan kebijakan dan keluaran kebijakan yang mengedepankan sikap arogan yang cenderung memihak kepada kepentingan pengusaha industri pertambangan dan bersandar pada logika investasi, dibanding menanggapi realitas pemiskinan masyarakat di sekitar tambang. Ketidakadilan lingkungan (environmental injustice) yang dilakukan oleh pemerintah lebih jelas dilihat pada Gambar 1.

Permasalahan lingkungan hidup seperti di atas dikemukakan pula oleh Fritjof Capra dalam bukunya The Web of Life yang menyatakan:

"As the century draws to a close, environmental concern have become of paramount importance. We are faced with a whole series of global problems that are harming the biosphere and human life in alarming ways that may soon become irreversible."13

Pendapat Capra menyatakan bahwa seiring dengan berakhirnya abad ke-20, masalah lingkungan menjadi hal yang utama. Serangkaian masalah-masalah global yang membahayakan biosfer dan kehidupan 
manusia dalam bentuk-bentuk yang sangat mengejutkan yang dalam waktu dekat akan segera menjadi tak dapat dikembalikan lagi.

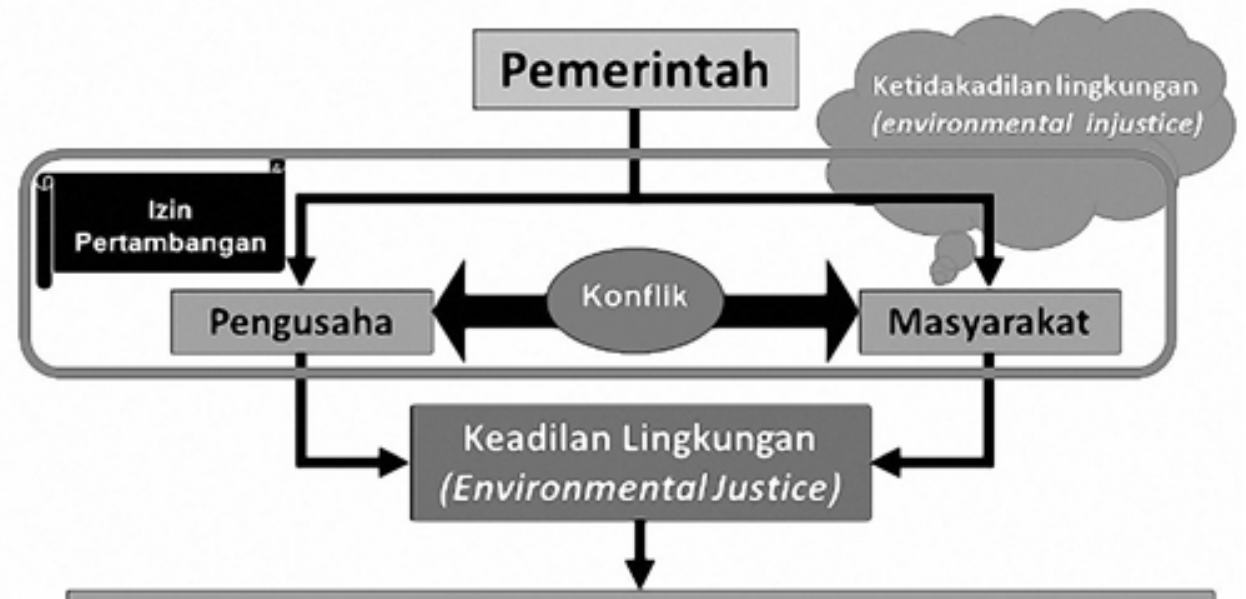

Pergerakan di lapisan masyarakat bawah yang memperjuangkan perlakuan yang sama bagi masyarakat tanpa memandang suku bangsa, budaya, sosial ekonomi, dalam hal pembangunan, implementasi dan penegakan hukum, peraturan dan kebijakan.

\section{Aspek keadilan lingkungan}

Gambar 1. Ketidakadilan Lingkungan (Environmental Injustice) yang Dilakukan Pemerintah

Soal ketidakadilan lingkungan hidup (environmental injustice) yang banyak terjadi di Indonesia sebagaimana diuraikan di atas sangat penting di tengah makin berkembangnya iklim demokrasi di berbagai negara, termasuk di Indonesia. Isu keadilan lingkungan telah menjelma dari sebuah gagasan yang terkesan abstrak menuju sesuatu yang harus diperjuangkan, seperti ungkapan Sonny Keraf, keadilan memang harus direbut. ${ }^{14}$ Agenda perubahan bagi keadilan lingkungan tidak akan mungkin dilaksanakan tanpa kekuatan politik yang signifikan dan luas, melibatkan berbagai elemen atau komponen penting dalam masyarakat, dan tentu saja didukung kaum intelektual yang punya komitmen pada pembaruan dengan memposisikan lingkungan pada arus utama.

Krisis lingkungan hidup global yang kita alami dewasa ini sebenarnya bersumber pada kesalahan fundamental-filosofis dalam pemahaman atau cara pandang manusia mengenai dirinya, alam, dan 
tempat manusia dalam keseluruhan ekosistem, yang dikenal dengan istilah pandangan dunia (worldview) yang diambil dari bahasa Jerman weltanschanung yang berarti perspektif atau pandangan terhadap dunia. Tentang kesalahan fundamental-filosofis pemahaman manusia terhadap alam ini dapat dilihat pada Gambar 2.

Pada gilirannya, kekeliruan cara pandang ini melahirkan perilaku yang keliru terhadap alam. Manusia keliru memandang alam dan keliru menempatkan diri dalam konteks alam semesta seluruhnya, seperti diungkapkan Albert Schweitzer yang menyatakan, "Kesalahan terbesar semua etika sejauh ini adalah etika-etika tersebut hanya berbicara mengenai hubungan antara manusia dengan manusia." Inilah awal bencana lingkungan hidup dan karena itu, pembenahannya harus pula menyangkut pembenahan cara pandang dan perilaku manusia dalam berinteraksi, baik dengan alam maupun dengan manusia lain dalam keseluruhan ekosistem.

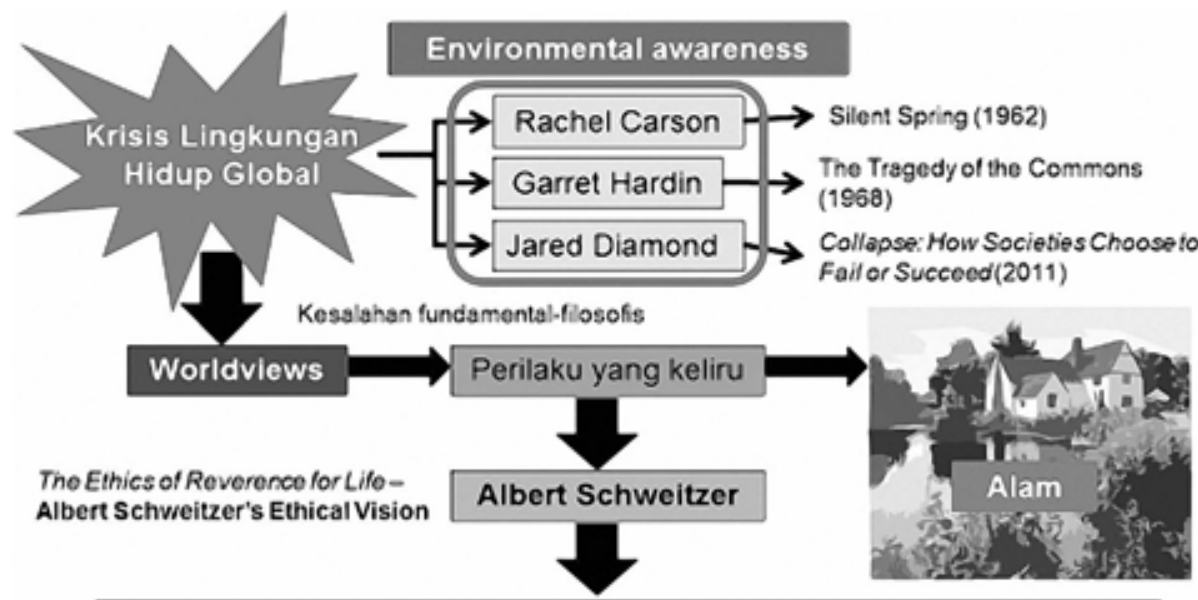

"Kesalahan terbesar semua etika sejauh ini adalah etika-etika tersebut hanya berbicara mengenai hubungan antara manusia dengan manusia."

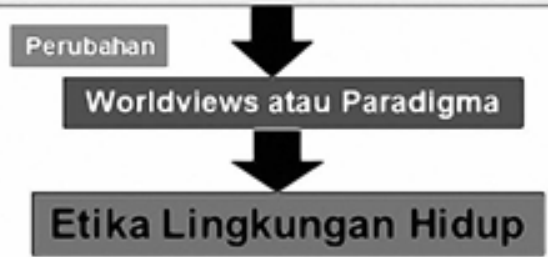

Masyarakat Adat Pengetahuan tradisional Kearifan lokal

Gambar 2. Kesalahan Fundamental-filosofis Pemahaman Manusia terhadap Alam

Persoalan lingkungan hidup merupakan persoalan moral, maka penyelesaian persoalan lingkungan hidup tidak dapat hanya didekati 
secara teknis parsial. Persoalan lingkungan hidup harus didekati secara lebih komprehensif-holistik, termasuk secara moral. ${ }^{15}$ Lingkungan hidup menurut Sonny Keraf bukan semata-mata hal teknis. Demikian pula, krisis ekologi global yang kita dewasa ini adalah persoalan moral, yakni krisis moral secara global. Oleh karena itu, perlu etika dan moralitas untuk mengatasinya. ${ }^{16}$ Nilai etika menurut Emil Salim dipengaruhi pertama-tama oleh pendalaman agama seseorang. Dalam perkembangan hidup manusia terdapat faktor-faktor lain yang turut mempengaruhi nilai-nilai moral manusia, yaitu kondisi lingkungan sosial dan lingkungan alam dalam mana manusia tumbuh berkembang. ${ }^{17}$ Emil Salim lebih lanjut menyatakan bahwa segi yang mempengaruhi hubungan manusia dengan lingkungan hidup ditentukan oleh etika lingkungan. Arne Naess mengungkapkan bahwa krisis lingkungan hidup dewasa ini hanya bisa diatasi dengan melakukan perubahan cara pandang dan perilaku manusia terhadap alam secara fundamental dan radikal. Dibutuhkan sebuah pola hidup atau gaya hidup baru yang tidak hanya menyangkut orang perorang, tetapi juga budaya masyarakat secara keseluruhan. Artinya, dibutuhkan etika lingkungan hidup yang menuntun manusia untuk berinteraksi secara baru dalam alam semesta. ${ }^{18}$ Etika adalah filsafat moral, atau ilmu yang membahas dan mengkaji secara kritis persoalan benar dan salah secara moral, tentang bagaimana harus bertindak dalam situasi konkret.

Kesalahan pola pikir dan pola tindak manusia dalam menyikapi alam dan mengelola berbagai energi dan meteri yangada di dalamnya telah membawa tragedi kemanusiaan terbesar berupa krisis lingkungan berkelanjutan. Semenjak revolusi industri dengan pabrik-pabrik dan peralatan teknologi masif yang makin pesat berkembang, eksploitasi dan destruksi pada entitas alam seperti spesies, individu dan ekosistem terjadi. Hal ini membuat manusia terhenyak dan memunculkan kesadaran terhadap gerakan-gerakan hijau, dan juga paham etika lingkungan dari sudut pandang filsafat lingkungan. Filsafat lingkungan merupakan filsafat baru yang diajukan oleh Henryk Skolimowski dalam Eco-Philosophy: Designing New Tactics for Living, yang mempertimbangkan hubungan antara satu individu dengan yang lain dan juga dengan lingkungan mereka, sebagai persandingan dengan filsafat kontemporer hasil modernisme. ${ }^{19}$

Cara pandang dan perilaku manusia dalam berinteraksi, baik dengan alam maupun dengan manusia lain dalam keseluruhan ekosistem, sesungguhnya telah ada di dalam masyarakat tradisional atau masyarakat 
adat dengan pengetahuan tradisional (traditional knowledge)-nya yang dikenal pula dengan kearifan lokal (local wisdom). Masyarakat tradisional atau masyarakat adat dengan pengetahuan tradisionalnya lebih mampu melestarikan lingkungan hidup dibandingkan dengan kehidupan modern. Masyarakat tradisional memiliki pengetahuan yang luas dan mendalam dalam perlindungan dan pengelolaan lingkungan hidup atau alamnya masing-masing, yang digunakan untuk mengelola sumber daya dengan sebaik-baiknya. Namun, seiring perkembangan zaman, berbagai peraturan perundang-undangan pada umumnya tidak mengakomodasi kepentingan masyarakat adat tersebut.

Sehubunga dengan krisis ekologi, Indonesia merupakan salah satu negara yang dikhawatirkan oleh Jared Diamond dalam Collapse: How Societies Choose to Fail or Succeed, mengingat krisis lingkungan dan ketidakbecusan pelaku negara mengelola dan menjaga sumber daya alam di negeri ini. Bila bangsa ini tidak segera sadar atas kesalahannya dalam mengelola alam dan dalam memperlakukan lingkungan hidupnya, peradaban bangsa ini akan segera punah. Diamond mengemukakan bahwa satu dari 5 (lima) faktor yang dapat menjadikan manusia dan peradabannya musnah yaitu kerusakan lingkungan yang disebabkan oleh manusia. Empat faktor lainnya yaitu perubahan iklim, musuh, kesalahan dalam menentukan partner usaha serta tindakan ekonomi dan politik masyarakat dalam menyikapi perubahan. Beberapa faktor penyebab runtuhnya suatu peradapan bangsa seperti yang disebutkan di atas sudah menjadi bagian yang melekat begitu lama dalam diri manusia. Diamond ${ }^{20}$ mencontohkan kepunahan bangsa Viking Norse di Skandinavia gara-gara secara tidak sengaja menyebabkan erosi dan penggundulan hutan sehingga menghancurkan sumber daya mereka. Diamond memasukan Indonesia, selain Nepal dan Kolombia, sebagai peradaban yang mungkin sudah dekat dengan keruntuhan. ${ }^{21}$

\section{Eco-Philosophy dan Etika Lingkungan}

Filsafat, seperti kehidupan, adalah suatu proses pemeriksaan kembali yang terus-menerus, karena filsafat adalah suatu penyulingan khas bagian sadar dari kehidupan kita. Filsafat adalah suatu bagian penting dari citra diri kita, yang kita bentuk dalam interaksi dengan dunia luar, dengan sejarah masa lampau kita dan mimpi-mimpi masa depan kita, sebagaimana diutarakan Skolimowski dalam bukunya. Skolimowski adalah profesor 
filsafat pada Departement of Humanities, University of Michigan, Ann Arbor. ${ }^{22}$ Ia lebih lanjut berpendapat:

"Without philosophy, we have no anchor, no direction, no sense of the meaning of life. Each epoch and each society is rooted in some fundamental beliefs and assumptions, which are acted upon as if they were true. They justify all other things that follow from them, while they themselves are accepted on faith.".23

Tanpa filsafat, kita tidak mempunyai jangkar, tidak mempunyai arah, tidak mempunyai pengertian akan makna hidup. Setiap zaman dan setiap masyarakat berakar dalam kepercayaan-kepercayaan dan asumsiasumsi yang fundamental. Mereka memberi pembenaran hal-hal lain yang diturunkan darinya, sementara mereka sendiri diterima hanya berdasarkan keyakinan.

Menurut Bambang Sugiharto, pada dasarnya filsafat adalah gerak nalar yang wajar, sealamiah bernapas, aliran pikiran yang pada titik tertentu tak bisa dibungkam dan dihentikan. Filsafat adalah sistematisasi pengalaman bernalar dan kecenderungan ingin tahu, yang telah kita miliki sejak masa kanak-kanak. Filsafat adalah pengalaman yang bergulat hendak merumuskan kerumitan dirinya yang sebenarnya tak terumuskan. Filsafat memampukan kita menyusun sendiri pegangan di antara berbagai informasi dan pendapat yang membingungkan, memampukan kita merumuskan sendiri makna pengalaman. Ketidakmampuan berpikir secara abstrak filosofis mudah mengakibatkan kerancuan-kerancuan berpikir yang menyedihkan dan berbahaya. Berbagai masalah berat negeri ini umumnya muncul karena kerancuan berpikir macam itu. Filsafat memang terdengar mengawang dan abstrak, tapi proses abstraksi itu diperlukan untuk menerangi pengalaman dan melihat akar-akar dasar tersembunyi di balik segala persoalan konkret. ${ }^{24}$ Tujuan filsafat yang sebenarnya menurut Louis O. Kattsoff adalah untuk menyusun suatu pandangan dunia. Pentingnya pandangan dunia mudah dimengerti bila kita memandang zaman kita sendiri. Zaman ini ditandai oleh pandangan dunia yang tampak tidak lengkap dan berada dalam proses perubahan. ${ }^{25}$

Suatu perubahan di dalam filsafat menurut Skolimowski adalah suatu perubahan dalam prinsip-prinsip utama keyakinan yang diterima, entah keyakinan itu berwatak religius atau sekuler. Dan sebaliknya, ketika suatu warga, masyarakat, atau peradaban tertentu diguncang atau 
dihancurkan, dibutuhkan pemikiran segar, yang faktanya, lebih sering merupakan suatu landasan filosofis yang baru. ${ }^{26}$

Sugiharto mengemukakan bahwa 'modernisme' di bidang filsafat adalah gerakan pemikiran dan gambaran dunia tertentu yang awalnya diinspirasikan oleh Descartes, dikokohkan oleh gerakan Pencerahan (Enlightement/Auflelarung), dan mengabdikan dirinya hingga abad kedua puluh ini melalui dominasi sains dan kapitalisme. ${ }^{27}$ Ia menjelaskan lebih lanjut mengenai gambaran dunia modernisme tersebut, beserta tatanan sosial yang dihasilkannya ternyata telah melahirkan berbagai konsekuensi buruk bagi kehidupan manusia dan alam pada umumnya. Pada taraf praksis, pandangan dualistiknya yang membagi seluruh kenyataan menjadi subjek dan objek, spiritual-material, manusia-dunia, dan sebagainya, telah mengakibatkan objektivisasi alam secara berlebihan dan pengurasan alam semena-mena, yang telah mengakibatkan krisis ekologi. ${ }^{28}$ Modernisme bidang filsafat sebagaimana dikemukakan oleh Sugiharto di atas merupakan filsafat kontemporer ${ }^{29}$ seperti yang diutarakan oleh Skolimowski. Filsafat kontemporer merupakan filsafat empirisis, analitis, yakni aliran ilmiah Barat dewasa ini. Filsafat tidak hanya mendominasi universitas-universitas Anglo-Saxon, tetapi secara tidak langsung telah menjadi filsafat yang diterima secara global. ${ }^{30}$ Skolimowski menyatakan:

"Kita berada pada periode kegemparan dan kekacauan yang lain, di mana kita harus menantang batas-batas pemahaman analitis dan empiris atas dunia seraya kita harus menyusun suatu kerangka kerja konseptual dan filosofis yang dapat menampung seabrek masalah sosial, etis, ekologis, epistemologis yang baru. Perlunya suatu kerangka kerja filosofis yang baru dirasakan oleh hampir setiap orang." 31

Skolimowski mencoba menawarkan filsafat lingkungan sebagai suatu tantangan yang memiliki persoalan-persoalan yang cukup signifikan untuk membuat para filsuf (dan bukan hanya para filsuf) merefleksikan, merenungkan, mengkaji ulang, mengusulkan wawasan, dan kebenarankebenaran baru. ${ }^{32}$ Ia mengajukan satu garis besar filsafat baru, yaitu filsafat lingkungan, yang mempertimbangkan hubungan antara satu individu dengan yang lain dan juga dengan lingkungan mereka. Jika diterima dan dijadikan landasan bertindak, filsafat lingkungan akan mengarahkan pada penyelesaian yang lebih mengembalikan makna yang hilang dari keberadaan manusia. Skolimowski menguraikan kekusutan beraneka ragam hubungan mekanistik dan fisik (yang membungkus dan mendefinisikan 
diri kita) untuk memperlihatkan bahwa sebagian besar krisis kita muncul karena alasan-alasan yang lebih fundamental. Krisis ini muncul karena kita telah membangun kode yang kurang baik untuk membaca alam, yang menyebabkan kekurangan dalam interaksi kita dengan alam. Akar penyebabnya terletak pada fondasi-fondasi pandangan dunia ilmiah kita, dan pada persepsi-persepsi yang dihasilkan pandangan dunia ini. Ia menyatakan,

“... most of our crises, ..., but arise for more fundamental reasons: they arise because we have constructed a deficient code for reading nature, leading to a deficiency in interacting with nature. The root cause lies in the very foundations of our scientific world view; and in the very perceptions which this world view engenders." 33

Skolimowski mengemukakan bahwa dalam memikirkan taktiktaktik baru untuk kehidupan, kita perlu memikirkan kembali hubunganhubungan kita dengan dunia pada umumnya, meninggalkan konsepsi dunia yang mekanistik, dan menggantikannya dengan konsepsi yang lebih luas dan lebih kaya. Filsafat lingkungan berusaha memberikan dasar-dasar konsepsi alternatifnya, yakni:

"... in devising new tactics for living we shall need to rethink our relationships with the world at large, ... we shall need to abandon the mechanistic conception of the world, and replace it with a much broader and richer one. Eco-philosophy attempts to provide the rudiments of this alternative conception." ${ }^{34}$

Filsafat lingkungan menurut Skolimowski berusaha membawa kembali koherensi antara sistem nilai manusia dengan pandangannya atas alam semesta supaya masing-masing akan menjadi aspek yang satu bagi yang lainnya, seperti dalam kebudayaan-kebudayaan tradisional. Filsafat lingkungan berusaha menyelamatkan individu bukan dengan pesan dangkal yang menenangkan ego kita, sementara bagian lain keberadaan kita masih tercabik-cabik, tetapi dengan cara melakukan rekonstruksi menyeluruh pada kosmologi kita, yang, bersama kebudayaan, menyusun matrik kesehatan (atau penyakit) kita. ${ }^{35}$

Etika lingkungan, menurut J. Baird Callicott, sebagai subjek disiplin ilmu tersendiri, muncul pada awal 1970-an sebagai tanggapan atas situasi tahun 1960-an ketika orang tiba-tiba sadar bahwa peradaban industrial telah mengakibatkan krisis lingkungan. ${ }^{36}$ Krisis lingkungan hidup dewasa 
ini, menurut pendapat Arne Naess, dapat diatasi dengan melakukan perubahan cara pandang (worldview) dan perilaku manusia terhadap alam secara fundamental dan radikal. Dibutuhkan sebuah pola hidup atau gaya hidup baru yang tidak hanya menyangkut orang perorangan, tetapi juga budaya masyarakat secara keseluruhan. Artinya, dibutuhkan etika lingkungan hidup yang menuntun manusia untuk berinteraksi secara baru dalam alam semesta.

Berbagai kasus lingkungan hidup yang terjadi sekarang ini, baik pada lingkup global maupun nasional, sebagai besar bersumber dari perilaku manusia. Masalah lingkungan hidup, menurut Sonny Keraf, adalah masalah moral, persoalan perilaku manusia. Maka, perlu etika dan moralitas untuk mengatasinya. ${ }^{37}$

\begin{tabular}{|c|c|c|}
\hline \multirow[b]{2}{*}{ Etika } & $\eta \hat{\eta} \theta 0 \varsigma ; \stackrel{\varepsilon}{\varepsilon} \theta 0 \varsigma$ & $\eta \theta \eta ; \eta \theta \varepsilon \alpha$ \\
\hline & $\begin{array}{l}\text { Bentuk tunggal ethos: accustomed place; } \\
\text { tempat tinggal yang biasa; padang } \\
\text { rumput; kandang habitat; kebiasaan, } \\
\text { adat; akhlak, watak; perasaan, sikap, cara } \\
\text { berpikir }\end{array}$ & Bentuk jamak:ethe atau ethea \\
\hline
\end{tabular}

Gambar 3. Kata Etika dalam Huruf Yunani Kuno

Istilah etika berasal dari bahasa Yunani kuno, ethos ( $\tilde{\tilde{\eta}} \theta$ os; dalam bentuk tunggal mempunyai banyak arti: tempat tinggal yang biasa; padang rumput; kandang habitat; kebiasaan, adat; akhlak, watak; perasaan, sikap, cara berpikir. Ta ethe $(\eta \theta \eta)$ atau ethea $\left(\eta \theta_{\varepsilon} \alpha\right)$ dalam bentuk jamak artinya: adat kebiasaan. Keraf menjelaskan mengenai etika secara teoretis sebagai berikut. Pertama, secara etimologis, etika berasal dari kata Yunani ethos (jamaknya: ta etha), yang berarti 'adat istiadat' atau 'kebiasaan'. Dalam arti ini menurut Keraf, etika berkaitan dengan kebiasaan hidup yang baik, tata cara hidup yang baik, baik pada diri seseorang atau masyarakat. Kebiasaan hidup yang baik ini dianut dan diwariskan dari satu generasi ke generasi lain. ${ }^{38}$ Kedua, etika dipahami juga dalam pengertian yang berbeda dengan moralitas. Dalam pengertian ini, etika dimengerti sebagai refleksi kritis tentang bagaimana manusia harus hidup dan bertindak dalam situasi konkret tertentu. Etika adalah filsafat moral, atau ilmu yang membahas dan mengkaji secara kritis persoalan benar dan salah secara moral, tentang bagaimana harus bertindak dalam situasi konkret. ${ }^{39} \mathrm{~K}$. Bertens berpendapat bahwa istilah etika dapat dipergunakan dalam tiga arti, yaitu: ${ }^{40}$

1. nilai-nilai dan norma-norma moral yang menjadi pegangan bagi 
seseorang atau suatu kelompok dalam mengatur tingkah lakunya. ${ }^{41}$

2. kumpulan asas atau nilai moral, yaitu kode etik. ${ }^{42}$

3. ilmu tentang yang baik atau buruk. Etika baru menjadi ilmu, bila kemungkinan-kemungkinan (asas-asas dan nilai-nilai tentang yang dianggap baik dan buruk) yang begitu saja diterima dalam suatu masyarakat - sering kali tanpa disadari - menjadi bahan refleksi bagi suatu penelitian sistematis dan metodis. Etika dalam arti ini sering disebut "filsafat moral". ${ }^{43}$

Kata 'moral' secara etimologis sama dengan etika, sekalipun bahasa asalnya berbeda. Kata moral berasal dari kata Latin mos (jamaknya: mores) yang berarti “adat-istiadat” atau 'kebiasaan'. Menurut Bertens, kata 'moral' dapat dipakai sebagai nomina (kata benda) atau sebagai adjektiva (kata sifat). Jika kata 'moral' dipakai sebagai kata sifat artinya sama dengan 'etis' dan jika dipakai sebagai kata benda artinya sama dengan "etika" yaitu nilai-nilai dan norma-norma yang menjadi pegangan bagi seseorang atau suatu kelompok dalam mengatur tingkah lakunya. 'Moralitas' (dari kata sifat Latin moralis) menurut Bertens mempunyai arti yang pada dasarnya sama dengan "moral", hanya ada nada lebih abstrak. Moralitas adalah sifat moral atau keseluruhan asas dan nilai yang berkenaan dengan baik dan buruk. ${ }^{45}$ Moralitas menurut Lawrence M. Friedman adalah kehendak untuk mengikuti norma-norma, karena semua itu adalah kehendak Tuhan, atau etika yang baik, atau kewajiban agama alih-alih karena hal itu berguna bagi kita atau bagi yang lainnya. ${ }^{46}$ Konrad Kebung memberikan perbedaan distingtif ${ }^{47}$ antara etika dan moral (moralitas). Kerap kali orang menyamakan kedua istilah etika dan moral, tetapi sebenarnya dua istilah ini memiliki perbedaan yang mendasar. ${ }^{48}$ Etika yang dipelajari sebagai ilmu sering juga disebut dengan nama filsafat moral. ${ }^{49}$ Dalam moralitas, menurut Kebung, penilaian dari luar terasa penting, dan penilaian ini justru memaksa saya untuk mematuhi hukum atau peraturan itu. Jadi, yang penting adalah hukum yang bersifat mewajibkan dan kewajiban itu disertai dengan sanksi hukum. Sementara itu, etika juga berhubungan dengan hukum dan peraturan atau kebiasaan umum, tetapi pelaksanaan atas hukum atau peraturan itu bukan karena kewajiban dari luar dan saknsi hukum. Pelaksanaannya sungguh didasarkan pada kesadaran batiniahpribadi (kebebasan pribadi), bahwa hukum dan peraturan itu baik bagi saya dan demi kebaikan saya sendiri. ${ }^{50}$ 
Mateus Mali menjelaskan bahwa biasanya kata etika dipakai untuk suatu analisis secara rasional atau filosofis tentang perilaku manusia. Kata 'etika' kadang-kadang juga dipakai untuk suatu studi fundamental tentang masalah-masalah manusia; sementara kata 'moral' dipakai sebagai referensi untuk suatu refleksi yang sifatnya religius atau untuk suatu referensi konkret tentang perilaku manusia. ${ }^{51}$

Setiap kejadian bencana alam (termasuk banjir) menurut Muh. Aris Marfai terjadi karena kesalahan pandang dan paradigma manusia dalam pengelolaan sumber daya alam dan lingkungan. ${ }^{52}$ Pengelolaan sumber daya alam dan lingkungan dipandang sebagai suatu kegiatan teknis operasional semata dengan tujuan untuk pemenuhan kebutuhan manusia dan kebutuhan segala bentuk-bentuk pembangunan secara materialitas. Marfai berpendapat bahwa dinegasikannya paradigma dan filosofi etik dan moralitas dalam pengelolaan dan pemanfaatan sumber daya alam dan lingkungan telah menjustifikasi segala bentuk kegiatan manusia yang justru memberikan dampak negatif dan efek kerusakan yang lebih besar terhadap sumber daya alam dan lingkungan itu sendiri. ${ }^{53}$

Permasalahan pengelolaan dan pemanfaatan sumber daya alam dan lingkungan bukan semata-mata merupakan permasalahan teknis operasional saja, melainkan perlu dilandasi etika dan moral. Pemanfaatan sumber daya alam dan lingkungan bukan sebagai bentuk eksploitasi terhadap alam dengan dalih bahwa segala sumber daya yang ada di bumi disediakan dan digunakan untuk sebesar-besarnya dalam pemenuhan kebutuhan hidup dan kehidupan manusia belaka. Moralitas lingkungan menurut Marfai mengedepankan sikap saling menghormati dan memberikan apresiasi terhadap berbagai komponen-komponen lingkungan yang ada (selain manusia) secara proporsional dan seimbang. ${ }^{54}$ Artinya, setiap komponen yang terkait dalam lingkungan dan ekosistem mempunyai nilai dan kemanfaatan tertentu sehingga hal tersebut tidak seharusnya dilanggar untuk menghindari ketimpangan dan krisis lingkungan. Pemahaman filosofis moralitas lingkungan ini sangat diperlukan dalam kaitannya dengan pemanfaatan sumber daya alam yang ada. Pemanfaatan sumber daya alam untuk pemenuhan kebutuhan manusia tidak saja hanya dipandang dari sudut pemenuhan kebutuhan materialitas dan pembangunan fisik semata-mata melainkan juga kebutuhan akan kualitas kehidupan yang lebih baik dalam arti luas. Moralitas lingkungan memberikan peluang hak 
dan kewajiban yang seimbang dari setiap komponen dalam ekosistem dan lingkungan untuk saling menghargai dan berfungsi secara sinergis. Moralitas lingkungan juga memberikan ruang gerak dan penghormatan terhadap interaksi antara manusia dengan manusia, manusia dengan komponen lingkungan lainnya, dan antar komponen lingkungan itu sendiri. Lebih jauh moralitas lingkungan memberikan penekanan pada bentuk pola pikir dan perilaku manusia dalam pengelolaan sumber daya alam dan lingkungannya. Sampai tahapan ini diharapkan fenomena krisis dan permasalahan lingkungan yang diakibatkan oleh segala bentuk pola pikir dan perilaku manusia dalam interaksinya dengan sumber daya alam dan lingkungan dapat direduksi. Implementasi dari filosofi moralitas lingkungan menurut Marfai diharapkan dapat mengurangi kejadiankejadian dari permasalahan lingkungan yang secara rutin terjadi setiap saat. $^{55}$

Etika lingkungan hidup menurut Sonny Keraf dipahami sebagai disiplin ilmu yang berbicara mengenai norma dan kaidah moral yang mengatur perilaku manusia dalam berhubungan dengan alam serta nilai dan prinsip moral yang menjiwai perilaku manusia dalam berhubungan dengan alam tersebut. ${ }^{56}$ Etika lingkungan hidup menurut Keraf adalah sebuah refleksi kritis tentang norma dan nilai atau prinsip moral yang dikenal umum selama ini dalam kaitan dengan lingkungan hidup dan reflesi kritis tentang cara pandang manusia tentang manusia, alam dan hubungan antara manusia dan alam serta perilaku yang bersumber dari cara pandang ini. ${ }^{57}$ Dari refleksi kritis ini lalu disodorkan cara pandang dan perilaku baru yang dianggap lebih tepat terutama dalam kerangka menyelamatkan krisis lingkungan, demikian menurut Keraf..$^{58}$

Etika lingkungan menurut Moh. Soerjani, dkk. adalah berbagai prinsip moral lingkungan. Jadi etika lingkungan merupakan petunjuk atau arah perilaku praktis manusia dalam mengusahakan terwujudnya moral lingkungan. Dengan etika lingkungan kita tidak saja mengimbangi hak dengan kewajiban terhadap lingkungan, tetapi etika lingkungan juga membatasi tingkah laku dan upaya untuk mengendalikan berbagai kegiatan agar tetap berada dalam batas kelentingan lingkungan hidup. ${ }^{59}$ Etika lingkungan oleh Suwito disebut dengan akhlak berlingkungan, baik sebagai standar ideal moral maupun dalam wujud perbutan. Sebagai sistem moral, akhlak tentu memiliki dasar normatif, yang dapat berasal dari akal 
pikiran dan ajaran tertentu seperti agama, atau gabungan keduanya. ${ }^{60}$

Dalam tulisan ini digunakan etika lingkungan dan moralitas lingkungan untuk merujuk hal yang sama terhadap perilaku manusia serta mencoba mengemukakan etika lingkungan hidup berdasarkan sejarah perkembangan pemikiran di bidang etika lingkungan hidup, yaitu antroposentisme, biosentrisme dan ekosentrisme. Etika ini mempunyai cara pandang (worldview) berbeda tentang manusia, lingkungan hidup, dan hubungan manusia dengan lingkungan hidup, sekaligus menentukan pola perilaku manusia dalam kaitan dengan lingkungan hidup. Dari ketiga teori etika lingkungan hidup tersebut saya menguraikan pada teori etika lingkungan hidup ekosentrisme sebagai berikut.

Antroposentrisme adalah teori etika lingkungan hidup yang memandang manusia sebagai pusat dari sistem alam semesta. Manusia dan kepentingannya dianggap yang paling menentukan dalam tatanan ekosistem dan dalam kebijakan yang diambil dalam kaitan dengan alam, baik secara langsung atau tidak langsung. Nilai tertinggi adalah manusia dan kepentingannya, hanya manusia yang mempunyai nilai dan mendapat perhatian, segala sesuatu yang lain di alam semesta ini hanya akan mendapat nilai dan perhatian sejauh menunjang dan demi kepentingan manusia. Oleh karena itu, alam pun dilihat hanya sebagai objek, alat dan sarana bagi pemenuhan kebutuhan dan kepentingan manusia. Alam hanya alat bagi pencapaian tujuan manusia. Alam tidak mempunyai nilai pada dirinya sendiri. ${ }^{61}$

Biosentrisme secara harafiah juga dikenal sebagai teori lingkungan hidup yang berpusat pada kehidupan (life-centered theory of environment). Inti teori biosentrisme adalah manusia mempunyai kewajiban moral terhadap alam. Kewajiban ini tidak bersumber dari kewajiban manusia terhadap sesama, sebagaimana dipahami antroposentrisme. Kewajiban ini bersumber dan berdasarkan pada pertimbangan bahwa kehidupan adalah sesuatu yang bernilai, entah kehidupan manusia atau kehidupan spesies lain. Etika lingkungan hidup bukanlah salah satu cabang dari etika manusia menurut teori ini. Etika lingkungan hidup justru memperluas etika manusia agar berlaku bagi semua makhluk hidup. Istilah biosentrisme erat kaitannya dengan istilah yang diungkapkan dalam karya filsul Paul Taylor, terutama dalam bukunya yang berjudul Respect for Nature: A Theory of Environmental Ethics. 


\begin{tabular}{|c|c|c|}
\hline & Bíos & $\mathrm{K}^{\prime} \dot{\varepsilon} \nu \rho O \nu$ \\
\hline Biosentrisme & $\begin{array}{l}\text { bio, berarti life atau } \\
\text { kehidupan }\end{array}$ & $\begin{array}{l}\text { kentron, berarti center } \\
\text { atau pusat }\end{array}$ \\
\hline
\end{tabular}

Gambar 4. Kata Biosentrisme dalam Huruf Yunani

Biosentrisme dalam Bahasa Inggris biocentrism, merupakan kata yang berasal dari bahasa Yunani, ßíos, bio, berarti life atau kehidupan; dan

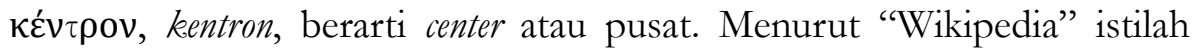
biosentrisme digunakan:

"in a political and ecological sense, is an ethical point of view which extends inherent value to non-human species, ecosystems, and processes in nature - regardless of their sentience. It stands in contrast to anthropocentrism which centers on the value of humans." ${ }^{\prime 2}$

Paradigma baru di bidang etika lingkungan yang menentukan pola perilaku manusia dalam kaitannya dengan lingkungan hidup, salah satunya yaitu ekosentrisme, sebagai kelanjutan dari teori etika lingkungan hidup biosentrisme. Ekosentrisme, dalam Bahasa Inggris ecocentrism, merupakan kata yang berasal dari bahasa Yunani, oĩkos, oikos, berarti house atau rumah;

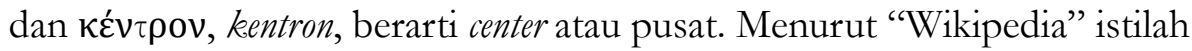
ekosentrisme digunakan, "in ecologicalpolitical philosophy to denote a nature-centered, as opposed to human-centred, system of values. The justification for ecocentrism usually consists in an ontological belief and subsequent ethical claim." ${ }^{33}$

\begin{tabular}{|c|c|c|}
\hline & ớKOS & $\mathrm{K \varepsilon ́} v \tau \rho O V$ \\
\hline Ekosentrisme & $\begin{array}{l}\text { oikos, berarti house } \\
\text { atau rumah }\end{array}$ & $\begin{array}{l}\text { kentron, berarti center } \\
\text { atau pusat }\end{array}$ \\
\hline
\end{tabular}

Gambar 5. Kata Ekosentrisme dalam Huruf Yunani

Ekosentrisme merupakan kelanjutan dari teori etika lingkungan hidup biosentrisme. Ekosentrisme memusatkan etika pada seluruh komunitas ekologis, baik yang hidup maupun tidak. Secara ekologis, saling terkait satu sama lain. Oleh karena itu, kewajiban dan tanggung jawab moral tidak hanya dibatasi pada makhluk hidup. Kewajiban dan tanggung jawab moral yang sama juga berlaku terhadap semua realitas ekologis.

Sebagai kelanjutan biosentrisme, ekosentrisme sering disamakan begitu saja dengan biosentrisme, karena ada banyak kesamaan di antara 
kedua teori ini. Kedua teori ini mendobrak cara pandang antroposentrisme yang membatasi keberlakuan etika hanya pada komunitas manusia. Keduanya memperluas keberlakuan etika untuk mencakup komunitas yang lebih luas. Pada biosentrisme, etika diperluas untuk mencakup komunitas biotis. Sementara pada ekosentrisme, etika diperluas untuk mencakup komunitas ekologis seluruhnya. ${ }^{64}$

Berbeda dengan biosentrisme yang hanya memusatkan etika pada komunitas biotis, pada kehidupan seluruhnya, ekosentrisme justru memusatkan etika pada seluruh komunitas ekologis, baik yang hidup maupun tidak. Secara ekologis, makhluk hidup dan benda-benda abiotis lainnya saling terkait satu sama lain. Oleh karena itu, kewajiban dan tanggung jawab moral tidak hanya dibatasi pada makhluk hidup. Kewajiban dan tanggung jawab moral yang sama juga berlaku terhadap semua realitas ekologis. ${ }^{65}$

Etika ekosentris ini berakar dalam cara berpikir yang holistik, dan bukan mekanistik, tentang seluruh kenyataan. Cara berpikir yang bolistik. (utuh-menyeluruh) ini mempunyai 5 (lima) asumsi, menurut Agus Rachmat W., sebagai berikut. ${ }^{66}$

a. Segala yang ada itu berhubungan satu sama lain hingga membentuk satu keseluruhan. Keseluruhan (totalitas) itu mempengaruhi setiap bagian pembentuknya; dan sebaliknya, perubahan yang terjadi di dalam salah satu bagian akan ikut merubah bagian yang lainnya serta keseluruhan itu pula. Jadi, misalnya, dalam sebuah ekosistem terjadi begitu banyak perubahan dalam bagian-bagiannya, pada akhirnya seluruh ekosistem itu akan ambruk.

b. Keseluruhan itu lebih besar daripada sekadar jumlah bagian-bagian pembentuknya. Prinsip yang mengatur suatu ekosistem bukanlah prinsip identitas yang menyatakan bahwa keseluruhan itu identik dengan jumlah total bagian-bagiannya, melainkan prinsip sinergi: penggabungan beberapa kekuatan menjadi satu kesatuan akan menghasilkan daya serta dampak yang lebih besar daripada bila masingmasing kekuatan itu bekerja sendiri.

c. Makna itu tergantung dari konteks. Berbeda dari mekanisme yang menandaskan bahwa setiap hal itu bersifat mandiri dan bisa dimengerti secara terisolir, maka holisme itu menandaskan bahwa setiap hal atau peristiwa itu memperoleh maknanya berkat hubungannya dengan hal 
lain dan berkat peranannya dalam keseluruhan.

d. Proses lebih utama daripada bagian-bagiannya. Suatu keseluruhan tertentu, misalnya suatu sistem sosial atau biologis, itu selalu bersifat terbuka serta dinamis, artinya senantiasa terdapat pertukaran serta perputaran materi dan energi antara suatu sistem dengan lingkungannya. Bagian-bagian pembentuk suatu keseluruhan tidaklah bersifat permanen, tetapi senantiasa berubah serta berganti berkat proses pertukaran dan perputaran energi tadi. Akibatnya, selalu bisa timbul hal serta susunan keseluruhan yang baru. Proses perubahan serta kreativitas itu adalah ciri hakiki dari kenyataan.

e. Manusia dan lingkungan alam yang bukan manusia itu membentuk satu kesatuan. Dalam holisme, tidak terdapat pertentangan dualistik di antara alam/kebudayaan. Manusia dan alam dipandang sebagai dua belahan dari satu sistem organisme kosmik yang sama. Dengan kata lain, holisme itu lebih memperhatikan kesinambungan, dan bukan pertentangan, di antara manusia serta alam dan berusaha mempelajari pengaruh timbal balik di antara manusia/masyarakat dengan lingkungan alamiahnya.

Salah satu versi teori ekosentrisme adalah teori etika lingkungan hidup yang sekarang ini populer dikenal sebagai deep ecology. Sebagai sebuah istilah, deep ecology pertama kali diperkenalkan oleh Arne Naess, seorang filsuf Norwegia, pada 1973. Naess kemudian dikenal sebagai salah seorang tokoh utama gerakan deep ecology hingga sekarang. Dalam artikelnya yang berjudul "The Shallow and the Deep, Long-range Ecological Movement: A Summary", Naess membedakan antara shallow ecological movement dan deep ecological movement. ${ }^{67}$

Deep ecology menuntut suatu etika baru yang tidak berpusat pada manusia, tetapi berpusat pada makhluk hidup seluruhnya dengan upaya mengatasi persoalan lingkungan hidup. Etika baru ini tidak mengubah sama sekali hubungan antara manusia dengan manusia. Yang baru adalah, pertama, manusia dan kepentingannya bukan lagi pusat dari dunia moral. Deep ecology justru memusatkan perhatian kepada semua spesies, termasuk spesies bukan manusia. Singkatnya, kepada biosphere seluruhnya. Demikian pula, deep ecology tidak hanya memusatkan perhatian pada kepentingan jangka pendek, tetapi jangka panjang. Maka, prinsip moral yang dikembangkan deep ecology menyangkut kepentingan seluruh komunitas ekologis. ${ }^{68}$ 
Kedua, etika lingkungan hidup yang dikembangkan deep ecology dirancang sebagai sebuah etika praktis, sebagai sebuah gerakan, artinya, prinsip-prinsip moral etika lingkungan hidup harus diterjemahkan dalam aksi nyata dan konkret. Etika baru ini menyangkut suatu gerakan yang jauh lebih dalam dan komprehensif dari sekadar sesuatu yang instrumental dan ekspansionis sebagaimana ditemukan pada antroposentrisme dan biosentrisme. Etika baru ini menuntut suatu pemahaman yang baru tentang relasi etis yang ada dalam alam semesta ini disertai adanya prinsip-prinsip baru sejalan dengan relasi etis baru tersebut, yang kemudian diterjemahkan dalam gerakan atau aksi nyata di lapangan. Dengan demikian, deep ecology lebih tepat disebut sebagai sebuah gerakan di antara orang-orang yang mempunyai sikap dan keyakinan yang sama, mendukung suatu gaya hidup yang selaras dengan alam, dan sama-sama memperjuangkan isu lingkungan hidup dan politik. Suatu gerakan yang menuntut dan didasarkan pada perubahan paradigma secara mendasar dan revolusioner, yaitu perubahan cara pandang, nilai, dan perilaku atau gaya hidup. ${ }^{69}$

Akar gerakan deep ecology telah ditemukan pada teori ekosentrisme umumnya dan kritik sosial dari Henry David Thoureau, John Muir, D.H. Lawrence, Robinson Jeffers, dan Aldo Huxley. Pengaruh Taoisme, Fransiskus Asisi, ${ }^{70}$ Zen Budhisme, dan Barukh Spinoza juga sangat kuat dalam teori-teori dan gerakan deep ecology. Hanya saja, deep ecology menjadi sangat terkenal dan digemari belakangan ini, terutama pengaruh dari berbagai tulisan Arne Naess. Naess sendiri mengakui bahwa deep ecology sebagai gerakan internasional sesungguhnya bermula dari Rachel Carson, ${ }^{71}$ yang melalui bukunya Silent Spring (1962), mengajak semua orang untuk melakukan perubahan mendasar di semua bidang untuk menyelamatkan lingkungan hidup.

Salah satu versi teori ekosentrisme yaitu etika lingkungan hidup yang saat ini dikenal dengan istilah deep ecology sebagaimana dijelaskan di atas. Deep ecology sering diterjemahkan ke dalam bahasa Indonesia menjadi ekologi 'dalam' untuk membedakan dengan ekologi 'dangkal' atau shallow ecology. ${ }^{72}$ Deep ecology adalah sebuah aliran filsafat yang didirikan oleh Naess di awal tahun 70-an.Sebagai sebuah aliran filsafat baru, paradigma deep ecology berbeda dalam memandang dunia jika dibanding dengan aliran filsafat sebelumnya, yaitu ekologi 'dangkal' (shallow ecology). Paradigma baru ini dapat dikatakan sebagai suatu pandangan dunia yang bolistik. 
Dunia dipahami sebagai suatu keseluruhan yang terpadu ketimbang suatu kumpulan bagian-bagian yang terpisah-pisah. Ia juga bisa disebut sebagai suatu pandangan ekologis. Istilah ekologis ini dipahami dalam arti luas, yakni kesadaran yang mendalam yang mengakui kesalingtergantungan fundamental semua fenomena dan fakta bahwa, sebagai individu dan masyarakat semuanya terlekat dalam dan bergantung secara mutlak pada proses siklis alam.

Dalam pemaknaan deep ecology, sifat holistik tidak berhenti pada pengertian hubungan fungsional antar bagian-bagian, yang pada masingmasing bagian terjadi saling ketergantungan. Lebih dari pada itu segera perlu ditambahkan adanya faktor keterhubungan dengan basis lingkungan alamiah dan basis sosialnya. Ketika berpikir tentang sepeda misalnya, persepsi yang muncul tidak hanya sebatas pada sepeda sebagai suatu keseluruhan fungsional dan karena itu mengerti kesaling-tergantungan bagian-bagiannya. Pandangan deep ecology mengenai sepeda mencakup pandangan holistik, tetapi segera ditambahkan persepsi tentang bagaimana sepeda tersebut terlekat dalam lingkungan alamiah dan sosialnya - dari mana didapat bahan mentahnya, bagaimana sepeda tersebut diproduksi secara massal, bagaimana pemakaiannya mempengaruhi lingkungan alamiah dan komunitas yang memakai, dan sebagainya.

Deep ecology menurut Suwito NS mencoba memadukan aspek spiritualitas agama dengan lingkungan (eco-spirituality), manusia bagian dari alam dan alam adalah suci dan sakral. ${ }^{73}$ Suwito berpendapat bahwa deep ecology dengan beberapa variasi temuan lebih dekat dengan eko-sufisme. ${ }^{74}$ Eko-sufisme menurut Suwito dapat berarti sufisme berbasis ekologi, artinya kesadaran spiritual yang diperoleh dengan cara memaknai interaksi antar sistem wujud terutama pada lingkungan sekitar. ${ }^{75}$ Eko-sufisme atau green sufisme adalah konsep baru sufi yang dikonstruk melalui penyatuan kesadaran antara kesadaran berlingkungan dan berketuhanan, yakni: ${ }^{76}$

1. kesadaran lingkungan (save it, study it, and use it) adalah bagian tidak terpisahkan dari kesadaran spiritual (spiritual consciousness). Mencintai sesuatu yang menjadi milik Tuhan sama merupakan bagian dari mencintai Tuhan;

2. mengupayakan adanya proses transformasi dari spiritual consciousness menuju ecological consciousness (tataran implementasi/gerakan). Tujuannya adalah keserasian semesta (barmony in natura) dan keserasian 
(kesesuaian, tawfiq) antara pelaku sufi dengan Tuhan. Kondisi ini yang kemudian membuahkan cinta timbal balik (antara manusia dengan Tuhan, manusia dengan manusia, dan manusia dengan alam semesta).

Berbeda ekologi 'dangkal' yang bersifat antropocentris, atau berpusat pada manusia, yakni manusia berada di atas atau di luar alam - manusia adalah sumber nilai dan alam dipandang bersifat instrumental atau hanya memiliki nilai guna, ekologi 'dalam' tidak memisahkan manusia atau apapun dari lingkungan alamiahnya. Benar-benar melihat dunia bukan sebagai kumpulan objek-objek yang terpisah tetapi sebagai suatu jaringan fenomena yang saling berhubungan dan saling tergantung satu sama lain secara fundamental. Ekologi 'dalam' mengakui nilai intrisik semua mahluk hidup dan memandang manusia tidak lebih dari satu untaian dalam jaringan kehidupan.

Deep ecology menurut Naess, dicirikan oleh pertanyaan-pertanyaan paradigmatik, yakni pertanyaan-pertanyaan mendalam tentang fondasifondasi utama pandangan dunia dan cara hidup yang bersifat modern, ilmiah, industrial, berorientasi pertumbuhan dan materialistis. Semua pertanyaan mendasar ini kembali dipertanyakan dari perspektif ekologis: dari perspektif hubungan kita satu sama lain, dengan generasi-generasi masa depan dan dengan jaringan kehidupan di mana kita adalah bagiannya. ${ }^{77}$ Ekologi 'dalam' sebagaimana dinyatakan Fritjof Capra, pada akhirnya tidak lain adalah kesadaran spiritual dan religius, yaitu ketika jiwa manusia dimengerti sebagai pola kesadaran dan ketika individu mengalami rasa memiliki, dari rasa keberhubungan kepada kosmos sebagai suatu keseluruhan. $^{78}$

David Ray Griffin berpendapat bahwa beberapa pemikir seperti Albert Schweitzer dan beberapa orang "deep ecologist", menolak gagasan "hierarki nilai" teoretis yang menganggap ada makhlukmakhluk yang memiliki derajat kepentingan lebih tinggi dari yang lain. Pendirian ini mencerminkan penolakan antroposentrisme, dan ini patut dihormati. Walaupun begitu, pengakuan adanya "demokrasi nilai intrinsik" tidak memberikan pedoman hidup dengan pilihan-pilihan yang dipaksakannya. ${ }^{79}$ Pada kasus Schweitzer keputusan untuk menyelamatkan jiwa manusia dengan membunuh binatang seperti mikroba, nyamuk, atau singa dibenarkan hanya dengan alasan bahwa kita secara alamiah perlu menyelamatkan jiwa kita sendiri. Hal ini berakibat teori etisnya 
dalam praktek kehilangan prinsip etis. Pemikiran postmodern berusaha mempromosikan penghormatan mendalam, sama dengan yang dilakukan kaum ekologis egalitarian, terhadap kesetimbangan dalam alam pada 3 (tiga) pokok berikut: ${ }^{80}$

1. Setiap makhluk memiliki nilai intrinsi, nilai makna dalam dirinya. Oleh sebab itu, bentuk-bentuk individu yang lebih tinggi, dengan pengalaman yang lebih kaya, secara definisi memiliki nilai intrinsik yang lebih tinggi;

2. Setiap individu juga memiliki nilai ekologis, baik positif atau negatif, terhadap ekosistem. Secara umum, semakin sedikit nilai intrinsik yang dimiliki suatu individu, semakin positif nilai ekologis spesiesnya terhadap ekosistem. Sebagai contoh, ekosistem planet akan berjalan dengan sangat baik tanpa manusia dan ikan lumba-lumba (bahkan lebih baik tanpa manusia), tetapi tidak demikian tanpa plankton dan cacing tanah; serta

3. Dalam memikirkan nilai keseluruhan setiap makhluk, kita tidak boleh hanya mempertimbangkan nilai dalam dirinya dan nilainya bagi makhluk fana lainnya (akhirnya ke ekosistem), tetapi jua nilainya bagi pengamalan ilahi. Pengalaman sangat menyeluruh ini bisa dianggap menghargai semua nilai ekologis yang positif selama mereka bisa merealisasikan nilai-nilai intrinsik serta menghargai nilai-nilai intrinsik demi mereka sendiri. Kita bisa menganggap menghargai semua nilai ekologis yang positif selama mereka bisa merealisasikan nilai-nilai intrinsik serta menghargai nilai-nilai intrinsik demi mereka sendiri. Kita bisa menganggap bahwa kualitas pengalaman manusia yang khas akan menyumbangkan bentuk khusus pemenuhan pengalaman ilahi. 


\section{Ekosentris}

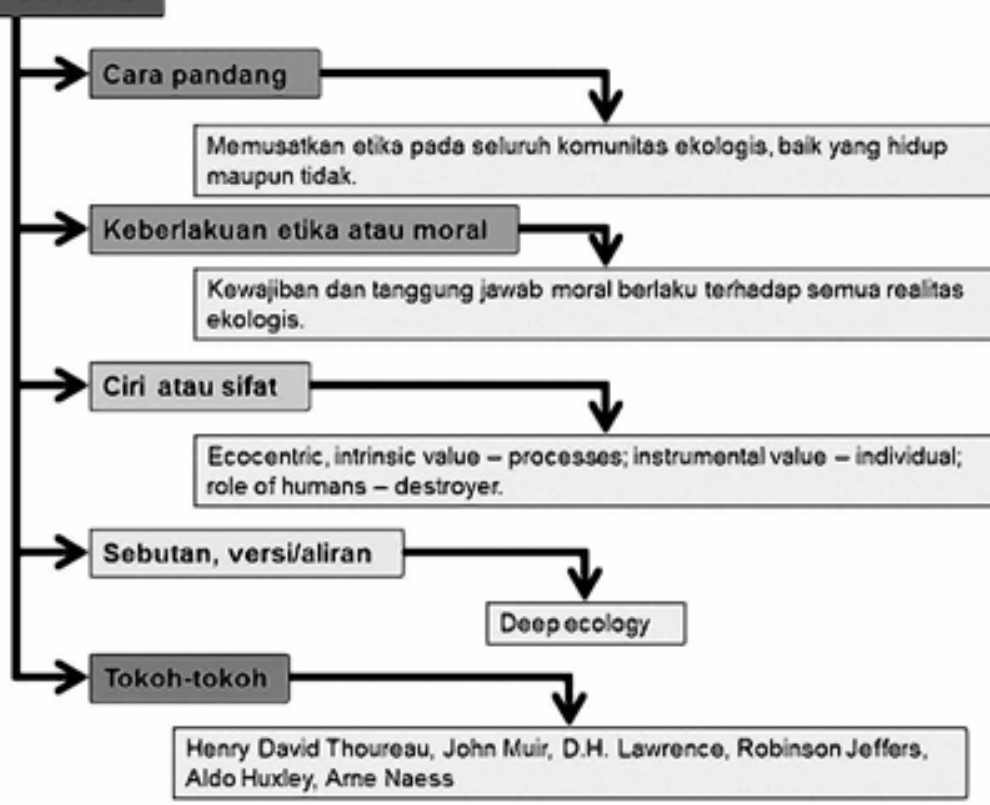

Gambar 6. Teori Etika Lingkungan Hidup Ekosentrisme

Dalam hubungan dengan tiga pokok di atas, menurut Griffin, kita sepenuhnya bisa menolak antroposentrisme yang menganggap alam secara instrumental belaka, tanpa bersikap ekstrem ke misantropi atau egalitarianisme ekologis. ${ }^{81}$

Dalam paradigma lama, ekologi 'dangkal' didasarkan pada nilainilai antroposentris (berpusat pada manusia), sedangkan dalam paradigma baru, ekologi 'dalam' didasarkan pada nilai-nilai ekosentris (berpusat pada bumi). Ekologi 'dalam' merupakan padangan dunia yang mengakui nilainilai yang melekat pada kehidupan nonmanusia. Semua mahluk hidup adalah anggota komunitas-komunitas ekologis yang terkait bersama dalam suatu jaringan yang saling bergantung. Teori etika lingkungan hidup ekosentrisme tersebut disketsa pada Gambar 6.

\section{Politik Hukum Lingkungan}

Aspek lingkungan memang tidak dapat dilepaskan dari kebijakan ekonomi, karena dalam sejarahnya kebijakan lingkungan muncul sebagai 
reaksi terhadap kegiatan ekonomi yang tidak berwawasan lingkungan. Hanya saja, persoalan lingkungan tidak semata-mata terkait dengan kegiatan ekonomi, melainkan terkait dengan semua aspek pembangunan. Oleh karena itu, sebaiknya aspek perlindungan lingkungan dimasukkan dalam pasal tersendiri di luar Pasal 33 UUD 1945 dalam rangka green constitution. Berdasarkan Pasal 28H ayat (1) dan Pasal 33 ayat (1) UUD NRI Tahun 1945, norma lingkungan hidup telah mengalami konstitusionalisasi menjadi materi muatan konstitusi sebagai hukum tertinggi (green constitution). Dengan demikian, segala kebijakan dan tindakan pemerintahan dan pembangunan haruslah tunduk kepada ketentuan mengenai hak asasi manusia atas lingkungan hidup yang baik dan sehat. Tidak boleh ada lagi kebijakan yang tertuang dalam bentuk undang-undang ataupun peraturan di bawah undang-undang yang bertentangan dengan ketentuan konstitusional yang pro-lingkungan ini (green legislation) atau dengan perkataan lain kebijakan yang bernuansa lingkungan hidup atau hijau harus tercermin dalam setiap peraturan perundang-undangan (green legislation) seperti diamanatkan Pasal 44 UU Nomor 32 Tahun 2009 dan tentu saja diperkuat dengan norma lingkungan hidup terkonstitusionalisasikan dalam UUD NRI Tahun 1945 (green constitution), yang diamanatkan Pasal 28H dan Pasal 33 ayat (4) UUD NRI Tahun 1945.

Persoalan lingkungan merupakan persoalan kebijakan, oleh karena itu persoalan lingkungan termasuk persoalan politik. Rachmad K. Dwi Susilo menyatakan bahwa membicarakan politik juga berarti membicarakan kekuasaan (power) dan kewenangan (authority). Membicarakan kedua-duanya akan sangat terkait erat dengan apa yang disebut sebagai kebijakan $\left(\right.$ policy). ${ }^{82}$ Oleh karena itu persoalan kebijakan di bidang lingkungan hidup merupakan kebijakan lingkungan hidup atau environmental policy. Kerusakan lingkungan hidup di Indonesia lebih besar disebabkan oleh kesalahan kebijakan negara daripada ulah tangan rakyat biasamenurut Chalid Muhammad. ${ }^{83}$ Arah kebijakan hukum di bidang lingkungan hidup itu disebut dengan politik hukum lingkungan. Politik hukum lingkungan merupakan arah kebijakan hukum yang ditetapkan oleh negara atau pemerintah untuk mencapai tujuan dan sasaran dari perlindungan dan pengelolaan lingkungan hidup. Namun, dalam kenyataannya hukum lingkungan seolah tidak mampu menjalankan fungsinya dengan baik dengan munculnya berbagai masalah lingkungan hidup, salah satu penyebab masalah-masalah lingkungan hidup, menurut Muhammad Akib, belum dipahami, dilaksanakan, dan ditegakkannya 
prinsip dan norma hukum lingkungan secara komprehensif sesuai dengan politik hukumnya. ${ }^{84}$

Hukum lingkungan merupakan cabang disiplin ilmu hukum yang berkaitan dengan pengaturan perlindungan dan pengelolaan lingkungan hidup serta pemanfaatan sumber daya alam. Hukum lingkungan sebagai cabang hukum yang memiliki karakteristik yang khas, tentu memiliki orientasi atau arah kebijakan yang khas juga. Arah kebijakan hukum tersebut secara sederhana disebut dengan politik hukum lingkungan. Arah kebijakan hukum tersebut secara formal terkait pula dengan asas-asas, aturan, dan instrumen-instrumen hukum apa saja yang akan diberlakukan dan ditegakkan dalam rangka mencapai tujuan perlindungan dan pengelolaan lingkungan hidup. Tujuan tersebut dapat lebih berorientasi kepada perlindungan dan pengelolaan lingkungan hidup, tetapi juga dapat untuk melagalisasi eksploitasi sumber daya alam secara tidak berkelanjutan. Dengan kata lain, ketentuan hukum lingkungan adakalanya juga tidak merefleksikan politik hukum yang berorientasi pada keberlanjutan ekologis secara holistik.

Hukum lingkungan yang materinya memuat berbagai prinsip dan norma hukum untuk mengelola lingkungan hidup, dalam realitasnya seolah tidak mampu menjalankan fungsinya dengan baik. Munculnya berbagai masalah lingkungan, menjadi bukti ketidakmampuan hukum lingkungan. Salah satu penyebabnya adalah belum dipahami, dilaksanakan, dan ditegakkannya prinsip dan norma hukum lingkungan secara komprehensi sesuai dengan politik hukumnya. Pemahaman tentang hukum lingkungan tidak cukup dengan membaca bunyi peraturan secara letterlijk, tetapi harus pula digali dan dipahami politik hukum yang terkandung di balik aturan hukum tersebut. Pemahaman ini penting agar pelaksanaan dan penegakkannya selaras dengan arah kebijakan hukum (legal policy) yang ditetapkan oleh pembentuk undang-undang. Guna memperjelas uraian di atas, dan untuk lebih mempermudah pembacaan, ditampilkan Gambar 7. 


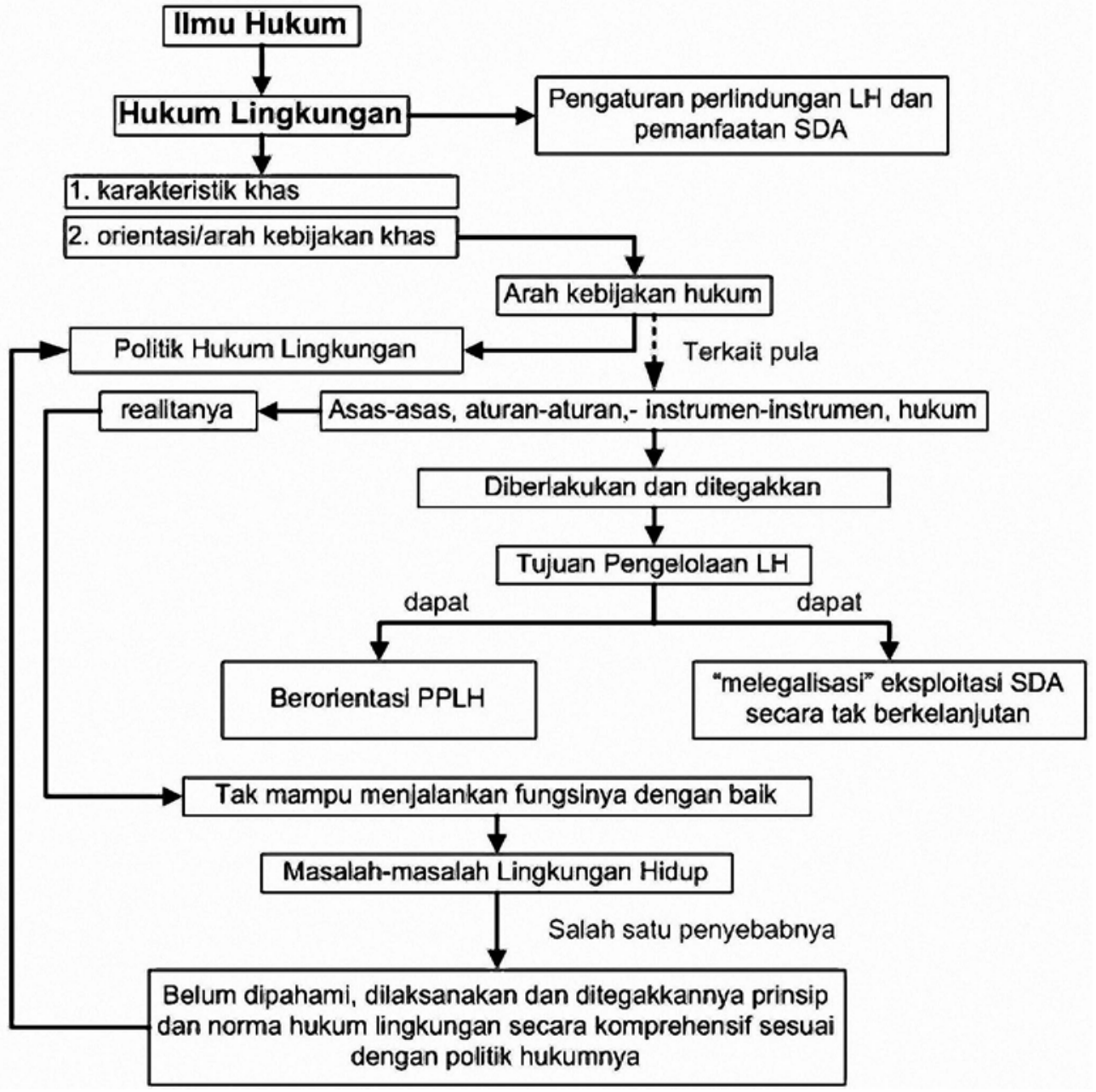

Gambar 7. Ciri Khas Hukum Lingkungan

\section{Simpulan}

Perubahan cara pandang (worldview) kita terhadap lingkungan dimulai dari etika dan moral lingkungan hidup. Etika lingkungan merupakan suatu arahan yang menjadi dasar manusia dalam berinteraksi dan berinterelasi dengan alam dan lingkungan. Etika lingkungan memberikan harapan yang nyata dalam menangani berbagai krisis dan permasalahan lingkungan yang terjadi pada dunia modern saat ini. Etika lingkungan ini mengakui bahwa kita merupakan bagian dari jaring-jaring 
kehidupan, etika yang memusatkan pada seluruh komunitas ekologis, baik yang hidup maupun tidak yang secara ekologis saling terkait satu sama lain. Oleh karena itu, kewajiban dan tanggung jawab moral tidak hanya dibatasi pada makhluk hidup. Kewajiban dan tanggung jawab moral yang sama juga berlaku terhadap semua realitas ekologis. Etika ekosentris ini berakar dalam cara berpikir yang holistik, dan bukannya mekanistik, tentang seluruh kenyataan. Paradigma baru di bidang etika lingkungan yang menentukan pola perilaku manusia dalam kaitannya dengan lingkungan hidup yaitu ekosentrisme (ecocentrism). Etika adalah filsafat moral, atau ilmu yang membahas dan mengkaji secara kritis persoalan benar dan salah secara moral, tentang bagaimana harus bertindak dalam situasi konkret. Filsafat, seperti kehidupan, adalah suatu proses pemeriksaan kembali yang terus-menerus, karena filsafat adalah suatu penyulingan khas bagian sadar dari kehidupan kita. Filsafat adalah suatu bagian penting dari citra diri kita, yang kita bentuk dalam interaksi dengan dunia luar, dengan sejarah masa lampau kita, dengan mimpi-mimpi masa depan kita.

Henryk Skolimowski mengajukan satu garis besar filsafat baru, yaitu filsafat lingkungan(eco-philosophy), yang mempertimbangkan hubungan antara satu individu dengan yang lain dan juga dengan lingkungan mereka. Jika diterima dan dijadikan landasan bertindak, filsafat lingkungan akan mengarah pada pemuasan dan penyelesaian yang lebih benar-benar mengembalikan makna yang hilang pada keberadaan manusia. Filsafat lingkungan berusaha membawa kembali koherensi antara sistem nilai manusia dengan pandangannya atas alam semesta supaya masing-masing akan menjadi aspek yang satu bagi yang lainnya, sebagaimana di dalam kebudayaan-kebudayaan tradisional.

Pemikiran ekosentrisme merupakan konsekuensi logis akibat perubahan global dari pemikiran yang semula semata-mata menekankan anthroposentrisme/homosentrisme. Lewat pandangan ekosentris, maka akan membawa perubahan besar terhadap tata hukum lingkungan internasional dan doktrin manusia sebagai makhluk penguasa satusatunya di bumi yang mempunyai partner sejajar, yaitu alam lingkungan/ lingkungan hidup. ${ }^{85}$ Teori ini dikembangkan berdasarkan tesis yang menetapkan lingkungan sebagai subjek hukum, baik sebagai perluasan doktrin hukum lingkungan klasik maupun berdasarkan teori-teori hukum baru yang mendasarkan kepada pendekatan ekologi daripada pendekatan 
homosentris. Lewat pemikiran tersebut, ajaran ilmu hukum mengalami kemajuan, sekaligus tantangan yang beriringan dengan kemajuan ilmu-ilmu lainnya. Kemajuan tersebut dibarengi dengan langkah-langkah mendasar dan konkret. Adanya peraturan yang jelas/tegas ditambah aparat yang jujur, tegas dalam bertindak, dan memiliki tangan yang kuat (strong arms) merupakan keharusan hukum.

\section{Bibliografi}

Abdillah, Mujiyono. Agama Ramah Lingkungan: Perspektif Al-Quran. Jakarta: Penerbit Paramadina, 2001.

Akib, Muhammad. Politik Hukum Lingkungan: Dinamika dan Refleksinya Dalam Produk Hukum Otonomi Daerah. Jakarta: Penerbit PT. RajaGrafindo Persada, 2013.

Asshiddiqie, Jimly. Konstitusi Ekonomi. Jakarta: Penerbit Buku Kompas PT. Kompas Media Nusantara, 2010.

Bertens, K. Etika. Jakarta: Penerbit PT. Gramedia Pustaka Utama, 2011.

Capra, Fritjof. The Web of Life: A New Scientific Understanding of Living Systems. New York: Anchor Books, 1996.

Chang, William. Moral Lingkungan Hidup. Yogyakarta: Penerbit Kanisius, 2001.

Diamond, Jared. Collapse: How Societies Choose to Fail or Succeed. New Hampshire: Marion Boyars Inc., 2011.

Djajadiningrat, Surna T. "Kebijaksanaan dan Hukum Nasional Pengelolaan Sumber Daya Alam Dilihat Dari Aspek Pembangunan Berkelanjutan" dalam Jurnal Hukum Lingkungan, Tahun IV Nomor 1, September 1997.

Friedman, Lawrence M. Sistem Hukum Perspektif Ilmu Sosial. Bandung: Penerbit Nusa Media, 2009.

Griffin, David Ray. Tuhan dan Agama Dalam Dunia Postmodern. Yogyakarta: Penerbit Kanisius, 2005.

Hardin, Garret. "The Tragedy of the Commons" dalam Majalah Science 162 (1968): 1243.

Indonesian Center for Environmental Law (ICEL). Membuka Ruang, Menjembatani Kesenjangan 1: Gambaran Akses Informasi, Partisipasi dan 
Keadilan Lingkungan di Indonesia. Jakarta: Penerbit Indonesian Center for Environmental Law (ICEL), 2006.

Kattsoff, Louis O. Pengantar Filsafat. Yogyakarta: Penerbit Tiara Wacana Yogya, 2004.

Kebung, Konrad. Filsafat Berpikir Orang Timur (Indonesia, Cina dan India). Jakarta: Penerbit Prestasi Pustakaraya, 2011.

Keraf, Sonny. "Pembangunan Berkelanjutan atau Berkelanjutan Ekologi" dalam Hukum dan Lingkungan Hidup Indonesia. Jakarta: Penerbit Universitas Indonesia, 2001. 2010.

Latif, Yudi. Menyemai Karakter Bangsa: Budaya Kebangkitan Berbasis Kesastraan. Jakarta: Penerbit Buku Kompas, 2009.

Lubis, Muchtar. Manusia Indonesia. Jakarta: Penerbit Yayasan Pustaka Obor Indonesia, 2013.

Marfai, Muh Aris. Moralitas Lingkungan, Refleksi Kritis Atas Krisis Lingkungan Berkelanjutan. Yogyakarta: Penerbit Wahana Hijau dan Kreasi Wacana, 2005.

Rachmat W., Agus. "Etika Lingkungan Hidup dan Pertentangan Politik" dalam Sugiharto, I. Bambang \& Rachmat W., Agus. Wajah Baru Etika dan Agama. Yogyakarta: Penerbit Kanisius, 2000.

Salim, Emil. Kembali Ke Jalan Lurus: Esai-esai 1966-99. Jakarta: Penerbit Alfabet, 2000.

Sessions, George. Deep Ecology: Living as if Nature Mattered. Layton, Utah: Gibbs Smith Publisher, 1985.

Skolimowski, Henryk. Eco-philosophy: Designing New Tactics for Living. New Hampshire: Marion Boyars Inc., 1981.

Soerjani, Moh., dkk. Lingkungan: Sumberdaya Alam dan Kependudukan dalam Pembangunan. Jakarta: Penerbit Universitas Indonesia (UI-Press), 2008.

Sugiharto, Bambang. Postmodernisme: Tantangan Bagi Filsafat. Yogyakarta: Penerbit Kanisius, 1996.

Sunarko, A. \& Kristiyanto, A. Eddy (Eds). Menyapa Bumi Menyembah Hyang Ilabi: Tinjauan Teologis atas Lingkungan Hidup. Yogyakarta: Penerbit Kanisius, 2008.

Susilo, Rachmad K. Dwi. Sosiologi Lingkungan. Jakarta: Penerbit PT. 
RajaGrafindo Persada, 2009.

Suwito NS. Eko-Sufisme: Konsep, Strategi, dan Dampak. Purwokerto: Penerbit STAIN Press \& Yogyakarta: Buku Litera, 2011.

\section{Endnotes}

1 Alvin Toffler, Future Shock (New York: Bantam Books, Inc., 1972) 3.

2 Ibid., 327-328.

3 Mohamad Soerjani, dkk., Lingkungan Hidup: Pendidikan, Pengelolaan Lingkungan dan Kelangsungan Pembangunan (Jakarta: Penerbit Yayasan Institut Pendidikan dan Pengembangan Lingkungan (IPPL), 2007) 28.

4 Sonny Keraf, Etika Lingkungan Hidup (Jakarta: Penerbit Buku Kompas, 2010) 2.

5 Raymundus Sudhiarsa, "Merumuskan Tanggung Jawab Iman dan Keberpihakan Pada Lingkungan Hidup" (2008) dalam A. Sunarko dan A. Eddy Kristiyanto, Menyapa Bumi Menyembah Hyang Ilabi: Tinjauan Teologis atas Lingkungan Hidup (Yogyakarta: Penerbit Kanisius, 2008) 186.

6 Muchtar Lubis, Manusia Indonesia (Jakarta: Penerbit Yayasan Pustaka Obor Indonesia, 2013) 5 .

7 Rachmad K. Dwi Susilo, Sosiologi Lingkungan (Jakarta: Penerbit PT. RajaGrafindo Persada, 2009) 132.

8 Chalid Muhammad, "Pulihkan Indonesia!”, Harian Kompas, Senin, 6 Juni 2011.

9 Muhammad Akib, Politik Hukum Lingkungan: Dinamika dan Reflesinya dalam Produk Hukum Otonomi Daerah (Jakarta: Penerbit PT. RajaGrafindo Persada, 2013) ix.

10 Jimly Asshidiqie, Konstitusi Ekonomi (Jakarta: Penerbit Buku Kompas, 2010) 283.

11 Ibid.

12 Jimly Asshidiqie, "Sumber Daya Alam: Pertimbangan Ekonomi Lebih Diutamakan", Harian Kompas, Selasa, 18 Oktober 2011.

13 Fritjof Capra, The Web of Life: A New Scientific Understanding of Living Systems (New York: Anchor Books, 1996) 3.

14 Sonny Keraf, op. cit.

15 Ibid., ix.

16 Ibid., 1.

17 Emil Salim, Kembali Ke Jalan Lurus: Esai-esai 1966-99 (Jakarta: Penerbit Alfabet, 2000) 190.

18 Arne Naess dikutip dalam Sonny Keraf, op. cit., 2.

19 Jared Diamond, Collapse: How Societies Choose to Fail or Succeed (New Hampshire: Marion Boyars Inc., 2011).

20 Jared Diamond, sebagaimana dikutip oleh Marison Guciano, "Bangsa Tanpa Visi Ekologi", Kompas, Jumat, 3 Februari 2012.

21 Ibid.

22 Henryk Skolimowski, Eco-philosophy: Designing New Tactics for Living (New Hampshire: Marion Boyars Inc., 1981) 21.

23 Ibid. 
24 Bambang Sugiharto, "Filsafat dan Pengalaman", Pengantar buku Jostein Gaarder, Dunia Sophie: Sebuab Novel Filsafat (Bandung: Penerbit Mizan) 14-15.

25 Louis O. Kattsoff, Pengantar Filsafat, Yogyakarta: Penerbit Tiara Wacana Yogya, 2004) 455.

26 Skolimowski, op. cit., 31-32.

27 Bambang Sugiharto, Postmodernisme: Tantangan Bagi Filsafat (Yogyakarta: Penerbit Kanisius, 1996) 29.

28 Ibid.

29 Filsafat kontemporer adalah cara pandang dan berpikir mendalam menyangkut kehidupan pada masa saat ini. Filsafat kontemporer memiliki sifat yang sangat heterogen. Filsafat kontemporer mensyaratkan kebebasan dan tidak selalu harus simetris. Aliran-aliran filsafat kontemporer antara lain: eksistensialisme, pragmatisme, postmodernisme, strukturalisme, fenomenologi, neo-thomisme, vitalisme, filsafat analitis.

30 Skolimowski, op. cit., 39.

31 Ibid., 33-34.

32 Ibid., 38.

33 Ibid., 2.

34 Ibid., 27-28.

35 Ibid., 40.

36 J. Baird Callicott, "Menuju Suatu Etika Lingkungan Global", dalam A. Sunarko dan A. Eddy Kristiyanto (eds.), Menyapa Bumi Menyembah Hyang Ilabi: Tinjauan Teologis atas Lingkungan Hidup (Yogyakarta: Penerbit Kanisius, 2008) 29.

37 Sonny Keraf, op. cit., 1.

38 Ibid., 14.

39 Ibid., 17.

40 K. Bertens, Etika, (Jakarta: Penerbit PT. Gramedia Pustaka Utama, 2011) 6.

41 Ibid.

42 Ibid.

43 Ibid., 6-7.

44 Ibid., 7.

45 Ibid.

46 Lawrence M. Friedman, Sistem Hukum Perspektif Ilmu Sosial (Bandung: Penerbit Nusa Media, 2009) 146.

47 'Distingtif', bersifat membedakan antara satuan-satuan bahasa.

48 Konrad Kebung, Manusia Makbluk Sadar Lingkungan (Jakarta: Penerbit Prestasi Pustakaraya, 2008) 39.

49 Ibid.

50 Ibid.

51 Mateus Mali, supra note 321, p. 137-138.

52 Muh Aris Marfai, Moralitas Lingkungan: Refleksi Kritis Atas Krisis Lingkungan Berkelanjutan (Yogyakarta: Penerbit Wahana Hijau (WEHA), 2005) 18.

53 Ibid.

54 Ibid., 20. 
55 Ibid., 21.

56 Sonny Keraf, op. cit., 40.

57 Ibid., 21.

58 Ibid.

59 Moh. Soerjani, dkk., Lingkungan: Sumberdaya Alam dan Kependudukan dalam Pembangunan (Jakarta: Penerbit Universitas Indonesia (UI-Press), 2008) 15-16.

60 Suwito NS, Eko-Sufisme: Konsep, Strategi, dan Dampak (Purwokerto: Penerbit STAIN Press \& Yogyakarta: Buku Litera, 2011) 28.

61 Sonny Keraf, op. cit., 47.

62 http://en.wikipedia.org/wiki/Biocentrism_\%28ethics\%29 (access 05.06.2012).

63 http://en.wikipedia.org/wiki/Ecocentrism (access 16.06.2012).

64 Sonny Keraf, op. cit., 92.

65 Ibid., 49-50.

66 Agus Rachmat W., "Etika Lingkungan Hidup dan Pertentangan Politik”, dalam I. Bambang Sugiharto dan Agus Rachmat W., Wajah Baru Etika dan Agama (Yogyakarta: Penerbit Kanisius, 2000) 75-76.

67 Sonny Keraf, op. cit., 50.

68 Ibid.

69 Ibid.

70 Fransiskus Asisi merupakan orang kudus pelindung lingkungan hidup, yang memanggil matahari sebagai 'Saudara Matahari'. Dengan menyaksikan setiap makhluk yang ditemuinya, maka dia melihat keberadaan Tuhan. Fransiskus Asisi diriwayatkan dalam sebuah perjalanannya melihat sekelompok burung, kemudian beliau meninggalkan rombongan, mendatangi kelompok burung tersebut lalu membacakan firman Tuhan dan berdoa: "Saudara-saudaraku para burung, seharusnya kalian bersyukur kepada sang Penciptamu, dan mencintaNya, Dia memberimu bulu yang indah sebagai pakaian, serta sayap yang membuatmu dapat terbang ke mana pun yang kau mau. Tuhan telah memberikan kekuasaanNya atasmu dibandingkan ciptaanNya yang lain, memberimu ruang gerak di udara segar, sehingga saat terbang kamu tidak pernah tertubruk atau tidak pernah pula terjatuh. Dialah yang melindungimu dari marabahaya dan mengatur hidupmu tanpa kamu merasakannya."

71 Rachel Carson lahir pada 1907 dan meninggal pada 1964. Ia mendapatkan gelar M.A. dalam bidang "zoology" dari John Hopkins University pada tahun 1932. Selama hidupnya, Carson mengabdikan diri dalam kegiatan penelitian, publikasi, dan perjuangan untuk menyadarkan umat manusia tentang pentingnya melestarikan lingkungan hidup. Lima buku yang ditulisnya yaitu: Under the Sea Wind (1941), Under The Sea-Wind (1941), The Sea Around Us (1951), The Edge of the Sea (1955), dan Silent Spring (1962) terus menerus dicetak ulang sampai sekarang. Karena itu, Carson dianggap sebagai peletak dasar bagi pengembangan studi tentang lingkungan hidup selanjutnya.

72 Sonny Keraf, op. cit., 17.

73 Suwito NS, op. cit., viii.

74 Orientasi pada keselamatan diri dapat diarahkan secara lebih positif dan berdampak baik pada lingkungan, jika diri/ego tersebut mencoba mengharmonikan diri pada ilahi, sesama, dan alam semesta.

75 Suwito NS, supra note 443, p. 47. 
MELINTAS 30.1.2014

76 Suwito NS, supra note 443, p. 47-48.

77 George Sessions, Deep Ecology: Living as if Nature Mattered (Layton, Utah: Gibbs Smith Publisher, 1985) 74.

78 Sonny Keraf, supra note 429, p. 18.

79 David Ray Griffin, 2005, Tuhan dan Agama Dalam Dunia Postmodern, Penerbit Kanisius, Yogyakarta, hlm. 48-49.

80 Ibid., 49.

81 Ibid., 49.

82 Rachmad K. Dwi Susilo, op. cit., 132.

83 Chalid Muhammad, art. cit.

84 Muhammad Akib, op. cit., ix.

85 Masyhur Effendi dan Taufani Sukmana Evandri, supra note 925, p. 54-55. 